\title{
New Technique Development For Anisakidae Detection In Fish Fillets
}

\author{
MaikonCésar Celestino de Souza ${ }^{1}$, João Pessoa Araújo Júnior¹, \\ MariannaVaz Rodrigues ${ }^{1 *}$ \\ ${ }^{1}$ Department of Microbiology and Immunology, Biosciences Institute, Univ. Estadual Paulista \\ (UNESP) at Botucatu, Distrito de Rubiao Junior, \\ *mvazrodrigues@gmail.com (MVR)
}

\begin{abstract}
The aim of this research was to highlight the importance of the study and prevention of Anisakis spp., which have no proper attention of producers and consumers. This work also describe a new technique development for worms detection that belongs to Anisakidae Family. This is an specific and sensitivemethod as revealed by the tests performed, and also presents easily application in seafood industry, and fast implementation when compared with candling table. The new method has low cost and allows to detect larvae from Anisakidae Family in any specie and any kind of fish, including fresh, frozen or even canned. This technique is based on muscle tissue digestion in a short time (15 seconds) and fast analysis of the parasites structures present by ultravioleta light (UV) observation.
\end{abstract}

Keywords: Anisakidae, Public Health, sanitary inspection, food safety.

\section{INTRODUCTION}

The increase of seafood intake is due to its nutrients, easily digestion, and bennefits to human health. Among nutrients, seafood has high quantity of proteins and polyunsaturated fatty acids, and low amount of fat (PRADO and CAPUANO, 2006). The Asian cookery and change in food behavior to get healthy food also influenced the increase intake of seafood (MATTOS, 2012).

Both freshwater and marine fish have many parasites that can cause economic losses to producer or industry due to production decrease, or by condemnation of the fillets highly parasitized. In the same way, some parasites can cause disease in human, which is an important risk to consumers (FERRER, 2001).

Bewteen fish-borne parasitic zoonosis, nematodes of Ascarida Order, Anisakidae Family are the most common in humans by intake of raw or uncooked seafood parasitized. The genus more frequently found in outbreaks areContracaecum, Anisakis, andPseudoterranova(OKUMURA et al., 1999).

The presence of Anisakislarva in the muscle tissue and internal organs has been described in many species of fish and cephalopods.The species of fish that are most parasitized are:Pirinampus pirinampu, Pseudoplatystoma fasciatum, Cyprinius carpio, Paulicea luetkeni, Hoplerythrinus unitaeniatus, Rhamdia quelen, Leporinus macrocephalus, Pseudoplatystoma corruscans, Pygocentrus nattereri, Serrasalmus marginatus, Brycon microleps, Salminus hilarii, Oreochromis spp., Hoplias malabaricus, and Salmo gairdneri (OTACHI et al., 2014).

The target of infection most common are the internal organs, but it is eliminated over the industrial processing of the seafood. The problem is that some types of helminths could migrate to the muscle, occurring zoonosis when the seafood is consumed incorrectly (RODRÍGUEZ, 1998).Thus, once the seafood is consumed raw, uncooked or cold smoked, associated with no control and prevention measures, this kind of food could be considered as a risk to human health(PRADO and CAPUANO, 2006).

The risk to get parasitosis is higher when the seafood is eated raw, normally when the consumer wants to preserve nutrients of this kind of food (YORIMITSU et al., 2013). When the end user is infected by Anisakis can presents gastrointestinal symptoms, allergy, and in severe cases, peritonitis and/or ascites (HOCHBERG et al., 2010). 
As objective, this research comes out the importance of the study and prevention of this nematode, which have no proper attention of producers and consumers. Another point is the development of a new technique to detect this worms in a fast and simple way in seafood fillets, when compared with candling table.

\section{MATERIALS AND METHODS}

\section{Parasites}

The Anisakid worms was obtained in a previous study (RODRIGUES et al., 2011) that found this parasites in Cynoscion spp. market in São Paulo municipality. During necropsy, the parasites observed was taken and identified by Amato et al. (1991) technique. After that, all nematodes were fixed in AFA. For this study, it was used only Anisakidae larvae of the genusAnisakis andContracaecum.

\section{New Method Development}

The first step was the contamination of the $40 \mathrm{~g}$ of the fillets (Thunnus albacares and Oreochromis niloticus) with 10 larvae of Anisakis. After that, they were mixed in a conventional mixer (Philips Walita $($ )with $400 \mathrm{~W}$ potency to helps the digestion. Thus, it was perfomed enzimatic digestion in environmental temperture $\left(22^{\circ} \mathrm{C}\right)$. For this purpose, it was used40 grams of muscle tissue previous mixed and $40 \mathrm{~mL}$ of buffer containing 15 grams of $1.4 \%$ papain and $\mathrm{HCl} 1$ Mto adjust $\mathrm{pH}$ to 5.0.

During enzimatic digestion, the samples were vortexed each 30 minutes to lead correctly homogenization. After 1 hour, the digested tissue was put in bags and closed. The observation of the material was performed incandling tableand inultravioleta light cabinet.

\section{ReSUlts}

The first test performed was the observation of the Anisakidae larvae in righteous fillets, which has no success. This test used fillets of Oreochromis niloticusand Thunnus albacares, where was posible to detect only the worms present in the surface and in thinner parts of seafood analyzed. As showed in figure 1, it was observed only little fluorescent structures.
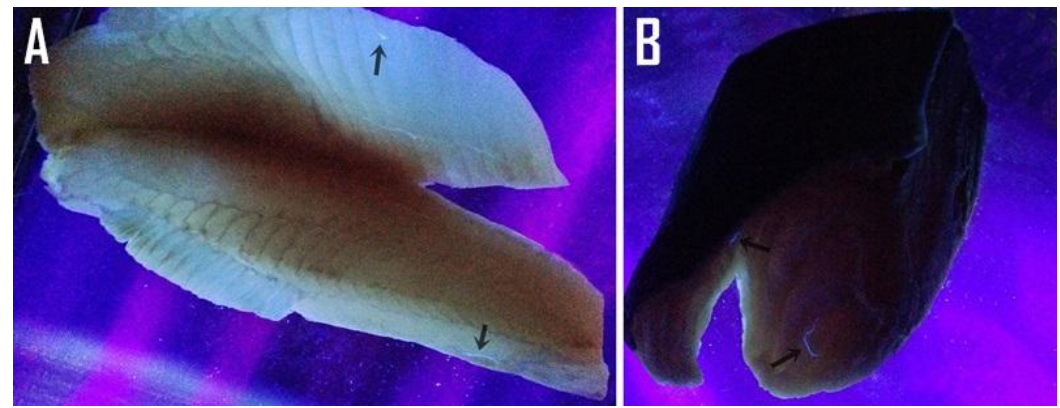

Figure1. Observation of Anisakidae worms in fish fillets. A: Oreochromis niloticus fillet. B: Thunnus albacares fillet.

Posteriorly, it was made tests with diferents times of enzimatic digestion: 1 hour, 2 hours, 3 hours, 4 hours, and 24 hours, followed by observation in candling tableand inultravioleta light cabinet.

The analysis of the observation performed in candling tablespent 2 minutes by each sample. This time is due to dificulty on the detection, once the larva is very similar to muscle structures, which was not totally digested(Figure2).

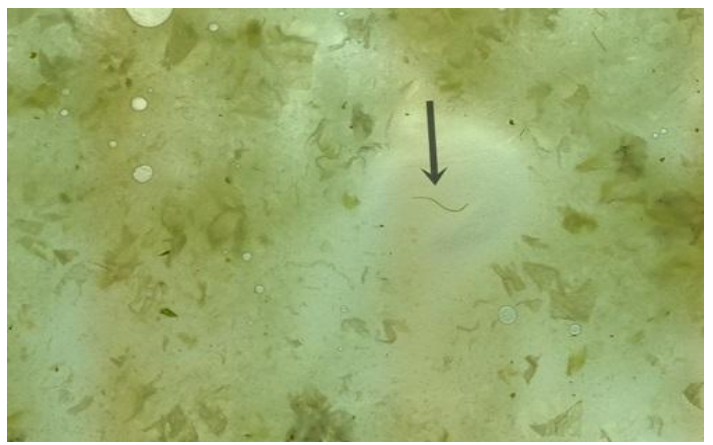

Figure2. Observation of Anisakidae larvae in candlingtable. 
The time spent for the evaluation in ultravioleta light cabinet was 15 seconds by each sample due to easily detection of fluorescence structures (Figure3).

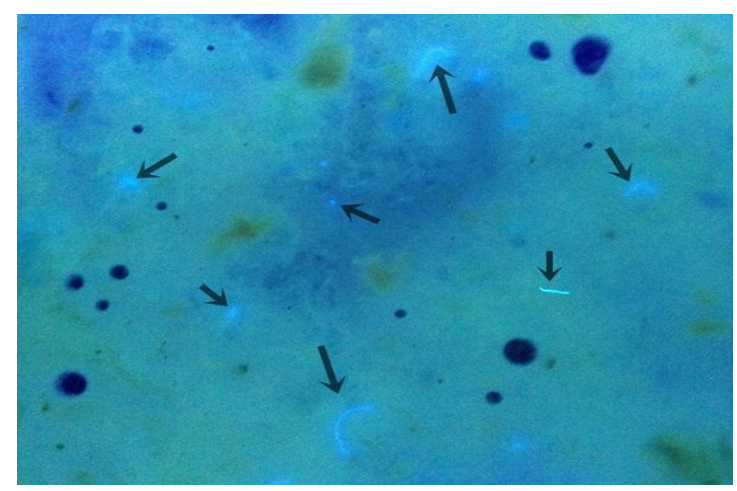

Figure 3. Observation of Anisakidae larvae in ultravioleta light cabinet.

Therefore, comparing the both techniques used to detect larvae, enzimatic and mixer digestion, followed by visualization in ultravioleta light cabinet was better than candling table due to low time for analysis and for require no experience of the inspector for it (Table 1).

Table1. Number of Anisakidae larvae detected by candling table and ultravioleta light cabinet in diferent times of digestion.

\begin{tabular}{|l|l|l|}
\hline Time of digestion & Candling table & Ultravioleta light cabinet \\
\hline $\mathbf{1}$ hour & 3 & 6 and fragments \\
\hline $\mathbf{2}$ hours & 5 & 5 and fragments \\
\hline $\mathbf{3}$ hours & 3 & 4 and fragments \\
\hline $\mathbf{4}$ hours & 5 & 8 and fragments \\
\hline
\end{tabular}

When time of digestion is analysed, we observe that 1 hour was enough to detect Anisakidae larvae in both visualization methods used in this research. However, ultravioleta light cabinet allows better observation because it detected even small larvae and fragments, which was formed by mixer homogenization.

It was also noted that long time of digestion could lead to unsuccess of this detection technique due to larvae digestion, which made the analysis more difficult (Figure4).

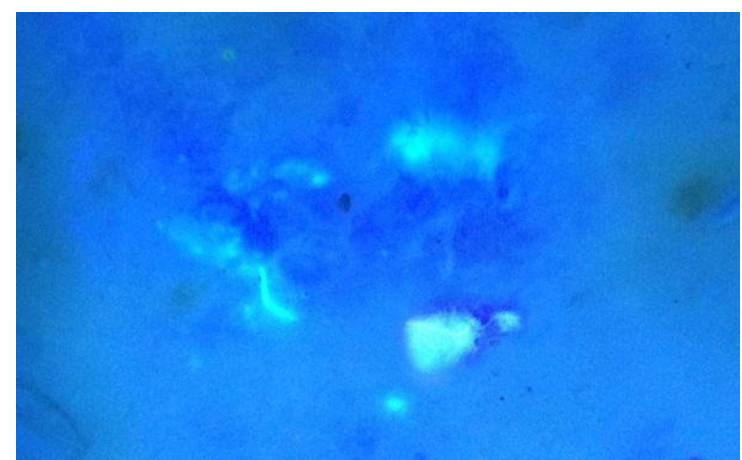

Figure4. Sample observation in ultravioleta light cabinet after 24 hours digestion.

It is important to highlight that was also performed only enzimatic digestion, without mixing the samples. This test result in more time of digestion ( 12 hours) due to integrity of the muscle, and for that reason, we estandardize with the two digestion: mixing and enzimatic.

\section{DisCUSSION}

Nowadays, the industrial detection of the nematodes in seafood is performed in a table with light incidence, called candling table. This tool has some limitation as thickness of the fillet analyzed, which could not pass more than 3 centimeters, as also it is influenced by the presence of skin, color of the muscle, and experience of the sanitary inspector. If nematodes are found, the part of seafood affected has to be discarded (ADAMS et al., 1997).

Codex Alimentarius (1999) informs that the presence of two or more parasites with 10 millimeter of length or when a cyst with 3 millimeter of diameter is present by kilogram of sample, commit the 
seafood quality. This information shows the importance of this study to easily detect larvae that could cause disease in humans or even causes economic losses.

Based on this, Dixon (2006) suggests that is necessary to perform microscopic analysis for parasites research and histological alterations observation that could compromise food safety. According to this author, the candling table must have:

- Glass with 30 x 60 centimetersand 5 to 6 millimeters of thickness;

- Lamp under 30 centimeters of the glass;

- Lamp with 1500 to 1800 lux;

- Environmental illumination with 500 lux.

Thus, due to dificulty of this tool mentioned above, it was developed a new technique that perform an enzimatic digestion of seafood muscle, which is observed by candling table and ultravioleta light cabinet.

With the obtained results of this study, it is possible to say that this is an easy and fast technique for parasite detection in seafood with low cost. After mixed and enzimatic digestion with papain (Carica papaya), the time spent for analysis in ultravioleta light cabinet pass to 15 seconds, once in candling table was about 2 minutes by each sample analyzed.

As Adams et al. (1997) and Dixon (2006) say about the limitations of the use of candling table, as thickness of the fillet analyzed, which could not pass more than 3 centimeters, as also is influenced by the presence of skin, color of the muscle, and experience of the sanitary inspector, the new technique developed in this study eliminated all them. Besides that, the time spent to analyse worms presence is very low due to fluorescent structures easily dectection.

Dixon (2006) concludes that candling table should not used for parasites detection in loin and steak, which are thick and for that reason the analysis not detects worms on them. This information corroborates to our results, which was observed that ultravioleta light cabinet is more efficient.

Celano et al. (2013) evaluate peptic digestion for Anisakidae larvae detection in ultravioleta light cabinet but only observed fragments. However, in this study, we observed not only fragments, but also whole nematodes, demonstrating its efficacy. Celano et al. (2013)yet report that the digestion method for fish fillet could be applied to enhance Anisakis spp. detection, which could be considered an valuable method for sanitary inspection in industry and even in caughtfield.

According to Food and Agriculture Organization (2008), visual inspection of the fish fillets only shows worms in the surface. In practice, this kind of inspection is effective for Phocanemadetection in fish fillets thin and without skin, specially those with white color. For that reason, candling table analysis is not usefull for others kinds of fillets such as those with dark color and thick (FAO, 2008).

Thus, between all advantages cited before to detect Anisakidae larvae, such as fluorescent structures easily detected, time and cost spent, it could be an important tool for sanitary inspector and for technical people that works with seafood quality.

\section{Conclusion}

The new method developed allows Anisakidae detection in any specie and any kind of seafood, including fresh, frozen or even canned. The advantages observed as fluorescent structures easily detected, time and cost spent, makes this technique usefull for sanitary inspector and for technical people that works with seafood quality.

Beyond Anisakid detection, this method allows visualization of other parasites with similar structures. The sensitive of this new technique is very high due to detection of little amount of parasites and samples analyzed.

\section{REFERENCES}

[1] Adams AM, Murrell KO, Cross JK. Parasites of fish and risk to public health. Revue Scientifique et Technique: Office International des Epizooties, Paris, France.1997.16: 652-660.

[2] Amato JFR, Boeger WA, Amato SB. Protocolos para Laboratório - Coleta e Processamento de Parasitos de Pescado. $1^{\text {st }}$ ed. 1991. 14-32. 
[3] Celano GV, Paparella A, Fransvea A, Balzaretti C, Celano G. Rapid Method for Detection of Anisakidae Larvae in Marine Fishes, Based on UV Transillumination. International Journal of Bioscience, Biochemistry and Bioinformatics. 2013. 3(4):392-394.

[4] Codex Alimentarius. Directrices del Códex para la evaluación sensorial del pescado y los mariscos en laboratorio. CAC/GL 31. 1999. 25p.

[5] Dixon BR. Isolation and identification of anisakis roundworm larvae in fish. Laboratory Procedure (OPFLP-2), Government of Canada. 2006. 7p.FAO. Round worms in fish.2007. Available in:< http://www.fao.org/wairdocs/tan/x5951e/x5951e01.htm $>$. Access: May $19^{\text {th }}$, 2016.

[6] Ferrer, I. Anisakiosis y otras zoonosis parasitarias transmitidas por consume de pescado. Aquatic.2001. 14: 1-21.

[7] Hochberg NS, Hamer DH, Hughes JM, Wilson ME. Anisakidosis: perils of the deep. Clinical Infectious Diseases. 2010.51(7): 806-812.

[8] Mattos DPBG. Aspecto sanitário e potencial alergênico de helmintos parasitos de peixes teleósteos marinhos do Estado do Rio de Janeiro, Brasil. Tesis. Universidade Federal Fluminense, Niterói, Rio de Janeiro. 2012. 14-20.

[9] Okumura MPM, Perez ACA, Spindola AF. Principais zoonoses parasitárias transmitidas por pescado - Revisão. Revista Educação Continuada do CRMV-SP. 1999. 2(2):. 66-80.

[10] Otachi EO, Magana AEM, Jirsa F, Fellner-Frank C. Parasites of commercially important fish from Lake Naivasha, Rift Valley, Kenya.Parasitology Research. 2014.doi: 10.1007/s00436-013$3741-4$.

[11] Prado SPT, Capuano DM. Relato de nematoides da família Anisakidae em bacalhau comercializado em Ribeirão Preto , SP. Revista da Sociedade Brasileira de Medicina Tropical. 2006. 39(6):580-581.

[12] Rodrigues MV, Del Fava C, Perez ACA. Presença do parasito anisaquídeo em pescada (Cynoscion spp.) como ponto crítico de controle na cadeia produtiva do pescado comercializado na Baixa Santista. Revista Higiene Alimentar. 2011. 25:151-155.

[13] Rodríguez, M. Parásitos de importância en la salud pública. Curso taller: Diagnóstico y control de enfermedades em peces de cultivo. Centro de Investigaciones Pesqueras. Ciudad de la Habana. Cuba. 1998. 345p. 